\title{
Walleye pollock Gadus chalcogrammus Pallas, 1814 found north of Spitsbergen indicates a Pacific-Atlantic connection in the species
}

\author{
Ingvar Byrkjedal' and Gunnar Langhelle ${ }^{\mid}$
}

\begin{abstract}
Byrkjedal I and Langhelle A. 2020. Walleye pollock Gadus chalcogrammus Pallas, 1814 found north of Spitsbergen indicates a Pacific-Atlantic connection in the species. Fauna norvegica 40: 137-140.

A small $(36.5 \mathrm{~cm})$ female walleye pollock Gadus chalcogrammus Pallas, 1814 was caught north of Spitsbergen in 2011. The specimen had a high number of pyloric caeca $(n=109)$, indicating a Pacific origin. The record is the first evidence of a possible input to the small Atlantic population of walleye pollock from the large populations on the Pacific side.
\end{abstract}

doi: 10.5324/fn.v40i0.3394. Received: 2020-01-21. Accepted: 2020-09-16. Published online: 2020-10-16. ISSN: $1891-5396$ (electronic).

Keywords: Gadoids, distribution, population exchange

1. Department of Natural History, University Museum of Bergen, University of Bergen, NO-5020 Bergen, Norway

Corresponding author: Ingvar Byrkjedal

E-mail:ingvar.byrkjedal@uib.no

\section{INTRODUCTION}

The walleye pollock Gadus chalcogrammus Pallas, 1814 has its primary distribution in the North Pacific, where it is abundant and of prime commercial value (Mecklenburg et al. 2018). A population also exists in the Northeast Atlantic, found mostly in the Barents Sea, from the coast of North Norway to as far north as near $76^{\circ} \mathrm{N}$ and east to $42^{\circ} 38^{\prime} \mathrm{E}$. The species does not occur in abundance in this region, and presently fewer than hundred specimens from this population are known to science (Christiansen et al. 2005, Privalikhin \& Norfvillo 2010, Zhukova \& Privalikhin 2014). Most of the Atlantic specimens have been caught as bycatch in commercial fisheries, especially on longlines set for other codfishes, such as Atlantic cod Gadus morhua Linnaeus, 1758 and haddock Melanogrammus aeglefinus (Linnaeus, 1758), off the coast of Finnmark (cf. Christiansen et al. 2005). Specimens caught have been in the size range of $46-71 \mathrm{~cm}$ (Christiansen et al. 2005, Zhukova \& Privalikhin 2014), and fully developed gonads have indicated spawning to take place somewhere in the Barents Sea region. Because no fry or juveniles have been recorded on the Atlantic side, we still do not know where these fish spawn, nor do we know their nursery grounds. The walleye pollock is considered to have an amphiboreal distribution. This range pattern is discussed by Mecklenburg et al. (2014), who point out that the lack of records in the Arctic Ocean between the Beaufort Sea and the Barents Sea might be due to negligible fishing activity in this area, as well as possible misidentification of small individuals. Morphological differences between the Atlantic and Pacific populations have been found (Byrkjedal et al. 2008). We here report on a specimen caught in 2011 north of Spitsbergen and discuss the possible origin of this specimen from examination of population-distinguishing characters.

\section{MATERIAL AND METHODS}

The specimen reported in this paper was caught on the RussianNorwegian ecosystem survey in the Barents Sea and around Svalbard Archipelago 9-24 August 2011 (cruise details, Anon. 2011, Rong 2012). The cruise is part of an annual research programme. The 2011 cruise applied bottom trawl (shrimp trawl, IMR code 3271) hauled for 15 minutes at 65 stations and pelagic trawl (IMR code 3514) hauled for 30 minutes at 43 stations distributed around the Svalbard Archipelago. CTD stations were undertaken at, or near, most of the trawl stations. Selected fish specimens were brought to the fish collections at the University Museum of Bergen for permanent storage for documentation of species distribution and, as appropriate, for genetic barcoding within the NORBOL project (http://www.norbol. $\operatorname{org} /)$. 


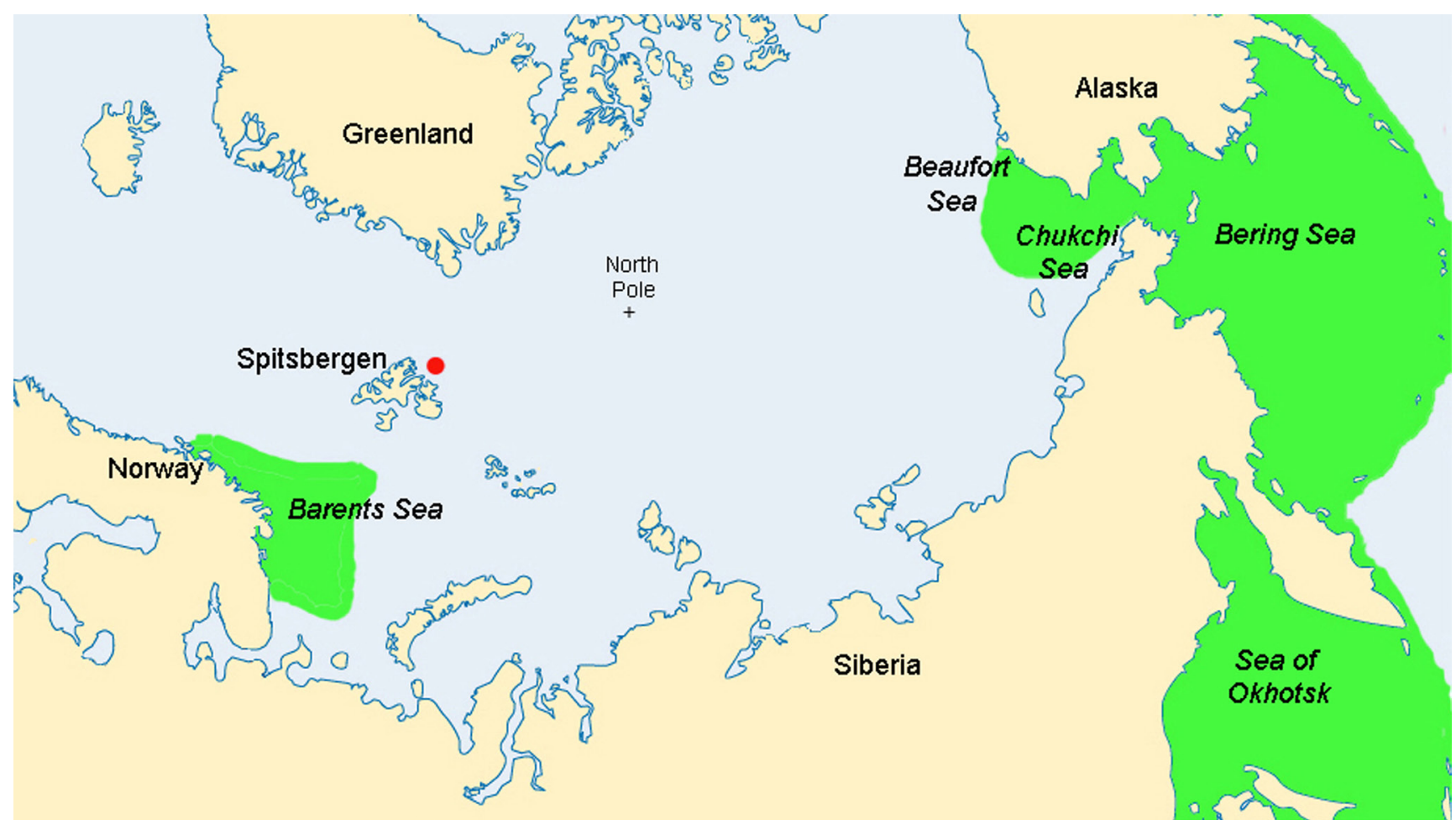

Figure I. Known distribution (shown in green) of walleye pollock in the Atlantic region and in the northern part of the Pacific region (after Mecklenburg et al. 2018). The record north of Spitsbergen shown by red dot.

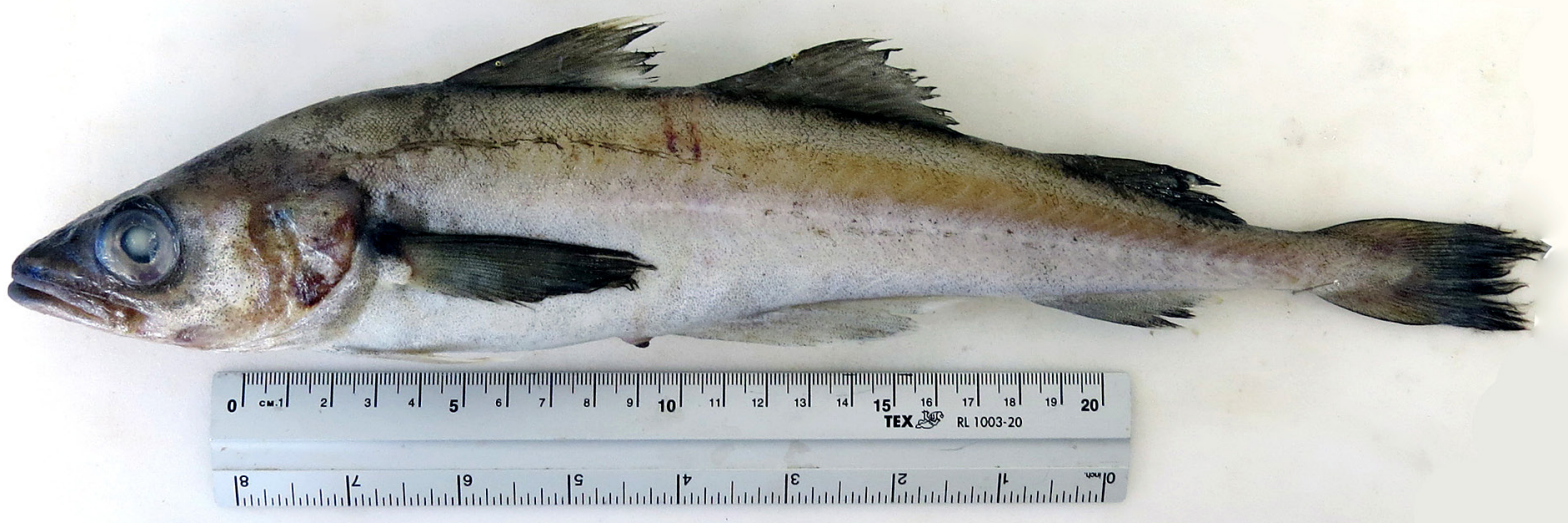

Figure 2. The specimen of walleye pollock caught north of Spitsbergen in August 2011.

\section{RESULTS}

The specimen of walleye pollock here reported was caught on 14 August 2011 north of Spitsbergen at $80^{\circ} 39^{\prime} \mathrm{N}-15^{\circ} 47^{\prime} \mathrm{E}$ (Figure 1), by bottom trawl at a gear depth of 274-267 m (R/F 'Helmer Hanssen', station 232, series 2055). The specimen (Figure 2) was kept frozen until thawed and fixed in $4 \%$ formalin at the Department of Natural History, University Museum of Bergen, and thereafter transferred to $75 \%$ ethanol for permanent storage in the collections, with the catalogue number ZMUB 22858. Its COI sequence is available at NORBOL with accession number CCDB-23718 E01.

Upon inspection of the fish after preservation, the specimen proved to be a female. From a histological examination, the ovary was judged to be in a resting stage or, that of a juvenile (A. Thorsen pers. comm.). Numbers of gillrakers on the upper branch of the first gill arch, and the number of pylorus caeca, have been found to differ between walleye pollocks in the Atlantic and the Pacific regions (Byrkjedal et al. 2008). The present specimen had 7 gillrakers on the upper branch on both left and right gill, and pylorus caeca amounted to 109.

This is so far the northernmost record of this species and, with a total length of $365 \mathrm{~mm}$ (measured before preservation took place) it is also the smallest specimen caught in the Atlantic.

\section{DISCUSSION}

In spite of a long history of annual fisheries research cruises (e.g., Jakobsen \& Ozhigin 2011, Wienerroither et al. 2011) in the Barents Sea and the waters around the Svalbard Archipelago, the walleye pollock has not been caught north of Spitsbergen before. But then again most of the known specimens from the Barents Sea have been caught in 
commercial fisheries with longlines, not by research cruises using trawl (Christiansen et al. 2005).

The question arises whether the specimen north of Spitsbergen is from the population found in the Barents Sea or, whether it originates from a Pacific population. A possible stray of the species from the Pacific to the Atlantic is speculated on by Mecklenburg et al. (2014). The species' range includes the Chukchi and Beaufort seas north of the Bering Strait (Mecklenburg et al. 2014, 2018), but great circle distance from there across the Arctic Sea to Spitsbergen is about $3000 \mathrm{~km}$, roughly three times that of the distance from north of Spitsbergen to the waters off Finnmark. This would make it likely that the specimen originated from the Barents Sea population. However, fishes from this population have been found to differ from those of the Pacific in number of pyloric caeca and to some extent in number of gill rakers (Byrkjedal et al. 2008), While 92-106 pyloric caeca were recorded in a Pacific sample, 57-91 were found in a Barents Sea sample, and the number of gill rakers on the upper branch of the first gill arch were 6-8 and 5-7, respectively. The number of gill rakers in the present specimen (7) is in the overlap zone, but the high number of pylorus caeca (109) would place the specimen in the Pacific group. The specimen represents the first evidence of possible crossing from east to west in the Arctic Ocean by the species, and thus lends support to the suggestion of Mecklenburg et al. (2014) that the Atlantic population could receive genetic contributions from the Pacific side. As pointed out by Mecklenburg et al. (2014) the genetic similarities between the Atlantic and Pacific populations (Coulson et al. 2006, Ursvik et al. 2007, Byrkjedal et al. 2008) might make one suspect that such does occur. With the species' patterns of movements showing little degree of site faithfulness in relation to spawning grounds, and with its wide temperature tolerance, such long-distance westward movements do not seem improbable (Mecklenburg et al. 2014). Walleye pollocks in the Chuckchi and Beaufort seas consist mainly of young individuals, and interestingly, the present specimen is the smallest so far caught in the Atlantic population, possibly a juvenile that had not yet spawned.

However, if the number of pyloric caeca can be considered a reliable population characteristic and not only a result of individual trophic adaptations to local conditions at an early ontogenetic phase (cf. Robinson \& Parsons 2002, Bolnick et al. 2003, Knudsen et al. 2008), the movement of fish from the Pacific side to the Atlantic is bound to be at a small scale, otherwise the morphological difference would not have been kept up over time.

In the Pacific waters the species rarely enters sub zero temperatures (Thorsteinson \& Love 2016). All previous records in the Atlantic waters (Mecklenburg et al. 2018) have been in above-zero water temperatures southwest of the polar front that runs more or less diagonally NW-SE in the Barents Sea (Jakobsen \& Ozhigin 2011). Also the present record from north of Spitsbergen was made in abovezero temperatures (Anon. 2011), in the branch of the Atlantic current that turns east around the north-western corner of Spitsbergen. The Arctic Ocean can be crossed between east and west in above-zero temperature water in the depth zone of 200-900 m (Coad \& Reist 2018); in the Pacific walleye pollock is found from near the surface down to $1200 \mathrm{~m}$ (Mecklenburg et al. 2014).

In the North Pacific the species spawns in deep water and, hatching in 2-3 weeks according to water temperature, the eggs rise towards the surface (Thorsteinson \& Love 2016). The epipelagic larvae transform after 60 days and live semibenthic in nearshore waters, going deeper as they grow. If spawning occurs in the temperate Atlantic water current, either in the deeper waters on the coast of Finnmark or, somewhere along the N-S slope on the western border of the Barents Sea, young fish should be expected to occur in waters on the west coast of Novaya Zemlya, or in waters west and north of Spitsbergen, as judged from the direction of the currents south and west of the Barents Sea polar front (Anon. 2011, Jakobsen \& Ozhigin 2011).We urge fisheries cruises to keep the species in mind in samples of small gadids in the Arctic, as confusion with ice cod Arctogadus glacialis (Peters, 1872) and even polar cod Boreogadus saida (Lepechin, 1774) is imminent, especially in large catches of any of these two species. A particularly useful identification character to look for in order to distinguish between young ice cod and walleye pollock, both of which have, contrary to polar cod, imbricate scales, slightly concave snout, and an eye diameter about the same length as the snout, is the appearance of the lateral line. While the trajectory of the lateral line is similar in the two species, the lateral line of walleye pollock constitutes a continuous line from its anterior starting point backwards to the downward bend of the line below the first/second dorsal fins after which the line becomes discontinuous. Ice cod has a lateral line that is discontinuous in its entire length (Mecklenburg et al. 2018).

A single specimen like the one reported here may not allow too strong conclusions. Any future specimens caught in the Arctic Ocean between the Chukchi and Beaufort seas and the Barents Sea would be highly interesting, especially if examined for number of pyloric caeca. Finding any spawning and nursery grounds in the Atlantic part of its distribution would also be most important to give an increased insight into the biology of the walleye pollock in the Atlantic.

\section{ACKNOWLEDGEMENTS}

We are very grateful to Anders Thorsen at the Institute of Marine Research, Bergen, for a histological examination of the ovary, and to an anonymous reviewer for comments on the manuscript.

\section{REFERENCES}

Anon. 2011. Survey report from the joint Norwegian/Russian ecosystem survey in the Barents Sea August-October 2011. IMR/PINRO Joint Report Series, No. 3/2011. 118 pp.

Byrkjedal I, Rees DJ, Christiansen, JS and Fevolden, S.-E. 2008. The taxonomic status of Theragra finnmarchica Koefoed, 1956 (Teleostei: Gadidae): Perspectives from morphological and molecular data. Journal of Fish Biology 73: 1183-1200. doi: 10.1111/j.1095-8649.2008.01958.x

Bolnick DI, Svanbäck R, Fordyce JA, Yang IH, Davis JM, Hulsey CD and Forister M. 2003. The ecology of individuals: incidence and implications of individual specialization. American Naturalist 161: $1-28$.

Christiansen JS, Fevolden S-E and Byrkjedal I. 2005. The occurrence of Theragra finnmarchica Koefoed, 1956 (Teleostei, Gadidae), 19322004. Journal of Fish Biology 66: 1193-1197. doi: 10.1111/j.00221112.2005.00682.x

Coad BW and Reist JD. 2018. Marine fishes of Arctic Canada. University of Toronto Press, Toronto.

Jakobsen T and Ozhigin VK. 2011. The Barents Sea: ecosystem, resources, management. Tapir Academic Press, Trondheim.

Knudsen R, Amundsen P-A, Jobling M and Klemetsen A. 2008. Differences in pyloric caeca morphology between Arctic charr Salvelinus alpinus ecotypes: adaptation to trophic specialization or parasite-induced induced phenotypic modifications? Journal of Fish Biology 73: 275-287. doi: 10.1111/j.1095-8649.2008.01934.x

Mecklenburg CW, Byrkjedal I, Karamushko O and Møller PR. 2014. Atlantic fishes in the Chukchi Borderland. Marine Biodiversity 44: 127-150. doi: 10.1007/s12526-013-0192-1 
Mecklenburg CW, Lynghammar A, Johannesen E, Byrkjedal I, Christiansen JS, Dolgov AV, Karamushko OV, Mecklenburg TA, Møller PR, Steinke D, and Wienerroither RM. 2018. Marine Fishes of the Arctic Region. Conservation of Arctic Flora and Fauna, Akureyri, Iceland. $739 \mathrm{pp}$.

Privalikhin AM and Norfvillo GV. 2010. On the finding of a rare species - Norwegian pollock Theragra finnmarchica Koefoed 1956 (Gadidae). Journal of Ichthyology 50: 143-147.

Robinson BW and Parsons KJ. 2002. Changing times, spaces, and faces: tests and implications of adaptive morphological plasticity in the fishes of northern postglacial lakes. Canadian Journal of Fisheries and Aquatic Sciences 59: 1819-1833. doi: 10.1139/f02-144

Rong V. 2012. Report on cruise and fixed oceanographic data stations, 2011. Fisken og havet 2/2012.

Thorsteinson LK and Love MS. 2016. Alaska Arctic marine fish ecology catalog. Scientific Investigations Report 2016-5038 Prepared in cooperation with Bureau of Ocean Energy Management, Environmental Studies Program (OCS Study, BOEM 2016-048). doi: 10.3133/sir20165038

Ursvik A, Breines R, Christiansen JS, Fevolden SE, Coucheron DH, and Johansen, SD. 2007. A mitogenomic approach to the taxonomy of pollocks: Theragra chalcogramma and T. finnmarchica represent one single species. BMC Evolutionary Biology 7: 86. doi: 10.1186/14712148-7-86.

Zhukova KA and Privalikhin AM. 2014. New data on distribution of Norwegian (Atlantic) pollock Theragra finnmarchica (Gadidae) in the Barents Sea. Journal of Ichthyology 54: 217-222.

Wienerroither R, Johannesen E, Dolgov A, Byrkjedal I, Bjelland O, Drevetnyak K, Eriksen KB, Høines Å, Langhelle G, Langøy H, Prokhorova T, Prozorkevich D and Wenneck, T de L 2011. Atlas of the Barents Sea Fishes. IMR/PINRO Joint Report Series 1-2011.

Editorial responsibility: Torkild Bakken.

This article is open-access and distributed under the terms of the Creative Commons Attribution 4.0 International license. This permits all noncommercial use, distribution, and reproduction in any medium, provided the original work is properly cited.

(http://creativecommons.org/licenses/by/4.0/). 